\title{
TERROR IN THE CAPITAL
}

Again, Jakarta rocked by bomb. Terrorism which did not show up after a long time, now has appeared near the centers of power - Sarinah, M.H. Thamrin Street - within a stone's throw to the State Palace. This event is quite shocking for two reasons. First, it has been a while since the act of terrorism does not appear with the assumption that the religious deradicalization program successfully executed and terrorist acts to focus more on Santoso cs group in Poso. Second, this action occured at a time when the executive, legislative and non-governmental organizations rowdy about the revision of anti-terrorism laws.

If traced back, the birth of terrorism laws preceded by devastating Bali bombing 1 incident. The incident speed up the delivery of terrorism laws which preceded the release of Government Regulation in Lieu of Law (PERPU). Although it is not as powerful as first Bali bombing, the bombing of Sarinah have similarities in terms of a situation where a revision of terrorism laws is being conducted. If nothing gets in the way, and with the similarity of the history, it appears that the revision of the law will not be encountering many obstacles, despite the various sections of the society, especially non-governmental organizations provide sharp criticism about the content of the material.

This incident is also a slap and at the same time damaging the country's image, because in this time Indonesia considered worthy to be used as a model in handling terrorism and deradicalization of religion. Nevertheless, the rapid movement of the police apparatus in handling of the case can be given the thumbs up, in a short time, these incidents can be addressed and the perpetrators can be apprehended, most of them directly shot on the spot.

The things we can take a note from this incident is beside the success of the police in dealing with terrorism, is the reaction of people who did not seem too scared, surprised nor trauma. Social media was busy talking about the public reaction that seems to see this incident as a mere entertainment, and some people even earn a fortune in the midst of terror. This proves that the communities' resilience to similar incidents have been tested. In any incident of terrorist raid, the same thing can also be found. Hopefully this can be social capital in combating terrorism in Indonesia in the present and the future.

Editor in Chief, 